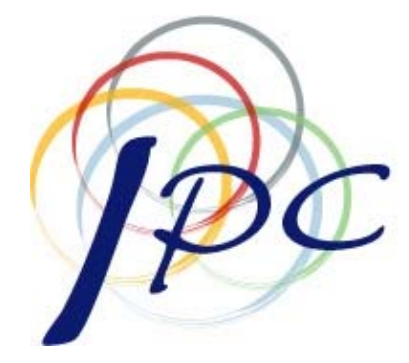

International Policy Center

Gerald R. Ford School of Public Policy University of Michigan

IPC Working Paper Series Number 42

Employment Elasticity in Organized Manufacturing in India

Dipak Mazumdar

Sandip Sarkar

April 2007 


\title{
EMPLOYMENT ELASTICITY IN ORGANIZED MANUFACTURING IN INDIA*
}

\author{
DIPAK MAZUMDAR \\ University of Toronto \\ And \\ SANDIP SARKAR \\ Institute of Human Development, Delhi
}

\begin{abstract}
This paper unravels a cyclical pattern in the value of employment elasticity in organized manufacturing in India over the period 1976-2002. Four periods are distinguished: the 'benign' growth period of the late seventies; the period of 'jobless growth' of the first half of the eighties; the 'reform period extending from the mid-eighties to the midnineties; and finally the post-reform period. The paper uses an integrated framework which quantifies the relative importance of the key factors determining of employment elasticity and its variations over the four periods. These are: (i) the relative movement of the indices of producer prices and consumer prices (sometimes called the DRER, the domestic real exchange rate); (ii) the share of wages in value added or alternatively by the parameter $\alpha$ used in this paper (defined as the elasticity of wages with respect to value added); and (iii) the trade-off between employment growth and wage growth. Section III provides an analysis of some key disaggregated groups within the sector. While the secular decline in the DRER rate is found to be important, two labor market variables (ii) and (iii) are instrumental in explaining the cyclical pattern.
\end{abstract}

*This work is part of a larger research project on Globalization, Labor Markets and Inequality in Asia funded by the International Development Research Center, Ottawa.

Correspondence: $\underline{\mathrm{d}}$ mazumdar@hotmail.com

Munk Centre for International Studies

University of Toronto

1 Devonshire Place

Toronto. Ontario M5S 3K7

Canada

April 2007 
The problem of low employment elasticity in manufacturing - that is, the feeling that employment growth has been lagging seriously behind output growth -- has been a serious issue in development economics since the sixties, when concerns about the employment problem in third world countries began to be discussed (see, for example, Morawetz 1974) It has been a particularly important matter of concern in India which has had a dismal record on employment generation in the 'organized (formal) manufacturing in recent years. The concern is a serious one for two basic reasons: first, formal manufacturing has been traditionally expected to take the lead in the generation of new productive employment and have large multiplier effects on the other sectors; and second, because of the huge labor productivity differential between the organized and the unorganized sectors, wage levels are at a much lower level in informal manufacturing, and so the dependence on the latter for manufacturing growth does not do much for raising living standards at the lower part of the distribution

In this paper we undertake a systematic analysis of the determinants of employment elasticity in Indian formal manufacturing based on the unit-level data available from the Annual Survey of Industry (ASI) conducted by the Central Statistical Office of the Government of India. The plan of the paper is as follows. In Section I we give an overview of the behavior over time in employment elasticity in this sector over the last four decades. We are able to classify the entire period into four sub-periods which reveal a cyclical pattern of the value of employment elasticity. The political economy of the four periods are explained. Section II sets out the outline of the decomposition model, used elsewhere by Mazundar (2003), which seeks to break down the different factors affecting the growth rate of employment given the growth rate of output (value added in constant prices). This section also goes beyond the earlier paper in setting out a model of the equilibrium of the firm which illuminates the economic process behind the decomposition model. The three factors shaping the value of employment elasticity are (i) the trend in the share of wages; (ii) the wage-employment trade-off; and (iii) the movement in the 'domestic real exchange rate' (DRER) or the ratio of the producer price index to the consumer price index. While the third is more a product of macro-economic factors, the first two are primarily labor market variables. The mechanics underlying the movements in the three variables are explained. The determinant of the wage 
share variable is explained in terms of a model which gives primacy to the firm' investment rate and its financing. In order to preserve the flow of the argument in the body of the paper, a full exposition of the model, and its testing with data from the ASI, is relegated to the Appendix. The results spelled out in Section III for the four periods distinguished show the relative importance of the three factors over the cycles. In Section IV we turn to some analysis with disaggregated sectors of formal manufacturing. In particular we discuss the experience of different sub-groups of industry distinguished by the dual criteria to exposure to world markets, and level of technology. Other topics include the private-public classification and disaggregation by size groups of firms. Section $\mathbf{V}$ summarizes some of the more important results.

\section{I}

\section{Classifying the periods of manufacturing growth in terms of Employment Elasticity}

The organized manufacturing sector in India has grown at different rates in different periods of its development in the last thirty years. At the same time employment elasticity-the rate of growth of employment relative to output growth has also varied enormously over these phases of growth. Figure 1 plots volume of employment against the real value added in manufacturing (at constant prices) in logarithmic scale, so that the slope of the curve gives an idea of the changing value of employment elasticity in different periods.

Figure 1: Employment and real GVA (1974-75 to 2001-2)

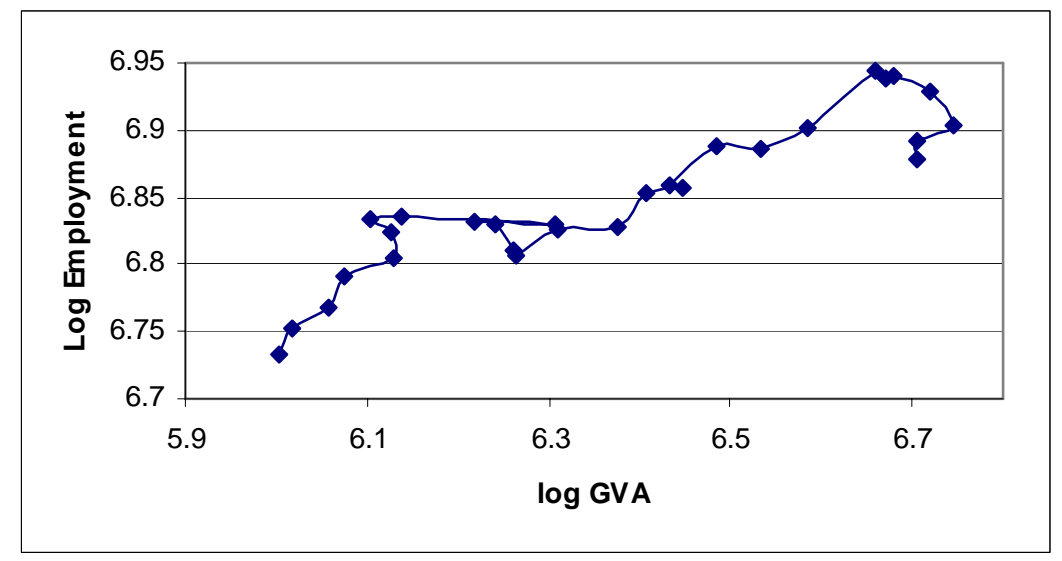

We are able to distinguish between four periods in terms of distinct breaks in the value of employment elasticity (i) 1974-1980 when employment elasticity had a high 
positive value of 0.99 (ii) the 1980-86 period of "jobless growth" when employment elasticity actually turned negative (with an average value of -0.16); (iii) the reform period of 1986-96 which saw a recovery of the employment elasticity to positive values (increasing to 0.33), although significantly lower than the value attained in the first period (iv) the post reform period 1996-2001. These periods also witnessed widely differing growth rates of value added. The data are given in Table 1 .

Table 1. Growth rate of Value added and employment elasticity

\begin{tabular}{|c|c|c|}
\hline Period & Value Added Growth & Employment Elasticity \\
\hline I 1974-1980 & 3.99 & 0.99 \\
\hline II 1980-86 & 6.21 & -0.17 \\
\hline III 1986-96 & 10.65 & 0.33 \\
\hline IV 1996-2002 & 1.75 & -1.39 \\
\hline
\end{tabular}

It turns out that the periods distinguished above are reasonably separate in terms of the politics of Indian economic policy. The beginning of the eighties has been identified by some researchers as an "attitudinal shift" towards private business on the part of the government (Rodrik and Subramanaian). "The change was inaugurated with the return of a much-chastened Indira Gandhi to political power in the 1980s after a three-year rule by the Janata Party... But the attitudinal change was grounded primarily in political calculation, and not in a desire to enhance to enhance the efficiency of the economic regime" (ibid, p.15). The motivation has been ascribed to Indira Gandhi's desire to undercut one prong of the support of the Janata Party coming from organized business groups. "This shift had more to do with currying favor with existing business interests (essentially large, politically influential firms in the formal manufacturing sector) than with liberalizing the system" (ibid). Rodrik and Subramanain had identified in a more detailed way the significant increase in growth rate -of organized manufacturing in particular - evident in the data of Figure 1 above. They also pointed out that when the industrial firms were operating so far below the production possibility frontier small changes in government policy-even of the 'attitudinal shift' kind could bring about a substantial response.

Indira Gandhi herself was not able to go through much substantial reform program even if she had planned to do so. After her assassination, it was left to Rajiv Gandhi to start on some pieces of substantive reform. It is customary to date the coming of reforms from 1991. This is because there liberalization on the external and trade accounts were only seriously addressed as part of the package agreed with the IMF after the serious balance of payments crisis of 1991. But as indicated above, the reform process had started earlier in a 
substantive way. The decade spanning the period stretching from the mid-eighties to the mid-nineties could be legitimately regarded as the reform period. This was the period that saw an upsurge of business optimism in the organized manufacturing sector, leading not only to a still higher growth rate of output, but also, as we shall see, a large lift in the investment ratio as manufacturing firms sought to build up their capacity. The overhang of the excess capacity of the controlled era of low efficiency had presumably been run down by the surge in output growth, starting at the beginning of the eighties.

The most recent decade has seen a post-reform recession. The windfall gains form the initial liberalization of the economy had been realized, and the manufacturing sector had to adjust to the more difficult problems of market growth in competitive environment. The reform process itself might have slowed down as policy makers and the various interest groups started to grapple with the thorny issues of continuing on the reform path. 


\section{II}

The Determinants of Employment Elasticity: A Conceptual Framework

This section discusses the conceptual framework for analyzing the significant factors determining employment elasticity which has been used for the analysis of the Indian data. It will hopefully identify the quantitative importance of some of the critical variables which have affected the growth of employment in Indian manufacturing, and the way they have varied over the four periods distinguished in the last section. The empirical results are presented in the next section following the discussion of the analytical framework.

Employment growth in manufacturing is obviously limited by the rate of growth of output or value added. But given the growth rate of output there are three important elements determining the value of the employment elasticity:

(i) The trend in the share of wages, i.e., the rate of growth of the wage bill relative to value added in current prices facing the producer $(\alpha)$;

(ii) The relative rates of increase in the producer and consumer price indices (sometimes called the domestic real exchange rate DRER) — which determines the value of the wage bill for the workers in terms of the prices facing them; and

(iii) The trade off between employment increase and real wage increase.

The process is shown in Figure II.1.

\section{Figure II.1: Determination of employment elasticity}

\section{Output Growth $\Rightarrow$ Wage bill growth $\Rightarrow D R E R \Rightarrow$ Wage bill growth $\Rightarrow$ Emp-Wage Tradeoff (producer prices) $\quad \alpha$ (producer prices) $\quad P_{p} / P_{c} \quad$ (consumer prices)}

We can use an algebraic decomposition, explained elsewhere (Mazumdar 2003) to quantify the different elements:

$$
\mathrm{L}^{\cdot}=\alpha \mathrm{v}^{\cdot}+\alpha \mathrm{P}_{\mathrm{p}}^{\cdot}-\mathrm{P}_{\mathrm{c}}^{\cdot}-\mathrm{w}^{\circ}
$$

where $\mathrm{w}$ is the real wage ( average earnings per worker); $\mathrm{v}$ is value added (in constant 
producer prices); $\mathrm{L}$ is employment; $\mathrm{P}_{\mathrm{p}}$ is the index of producer prices and $\mathrm{P}_{c}$ index of consumer prices; and $\alpha$ is a technological and behavioral parameter which is assumed to remain constant over the period under consideration. A variable written with a dot on top (') represents the proportionate rate of change of the variable concerned.

$\alpha$ defines the rate of growth of the wage bill related to the growth rate of output and hence determines the trend of the share of wages over the time-period being considered. The relative movements of the producer price and the consumer price indices, sometimes called the 'domestic real exchange rate' (DRER) translates the wage bill growth into real terms (in terms of consumer prices. The negative relationship between $\mathrm{w}^{\cdot}$ and $\mathrm{L}^{\cdot}$ clearly shows the wageemployment trade-off i.e., the way the growing wage bill cake is divided between wage increase and employment increase.

If the firm has no external source of finance, and cannot either accumulate or draw down financial reserves, then it must balance its books in every period, and equation (1) is an identity. But no firm can be expected to behave in this way. Generally it would have means of external borrowing, but in order not to face bankruptcy, it will aim at achieving a target gearing ratio. This target has to be reached, not on a day-to-day basis, but over a period of time - usually determined by its accounting period of consequence. Equation (1) then becomes a condition of equilibrium of the firm which enables it to maintain a stable gearing ratio over time. The model then has to be completed by a theory of the equilibrium of the firm in which the interconnected variables would force the firm towards this equilibrium.

The formal model and its testing with Indian data are to be found in Appendix 2. Here we present an overview of the relationships.

\section{The Model of the Firm and its Equilibrium}

We have assumed that one of the key determinants of employment elasticity - the DRER - is an exogenously determined variable. Prices of both producer goods and consumer goods are given to the firm. This of course means that our firm is a competitive one and a pricetaker in the goods market. It does not have the ability to influence either the price of its product or the price of the wage goods. In a more general framework these assumptions, particularly the first one might be dropped, but this issue is not addressed here.

The other two, the share of wages and the wage-employment trade-off, are both labor market variables. They are tied together in neo-classical economics by the supply functions of 
labor and of capital working through the production function. Together they determine the share of wages, the level of employment and the wage per worker.

Economists have in more recent discussions recognized the importance of expectations both in the determination of the wage per worker and the share of wages. Thus the difference between the neo-classical tradition, stressing the dominance of factor supply functions, and the postKeynesian tradition, emphasizing the importance of decisions originating on the employers' side, have been reduced.

In post-Keynesian models the independence of the investment function from the general savings function is stressed. There is a long tradition in economics which has worked with the idea that firms finance investment principally from the internal surpluses generated by the firm. Even though we have external financing the need to achieve the target gearing ratio effectively makes internal sources the principal source of investment. Thus the share of profits in value added is the crucial variable here. In fact it can be postulated that it is the investment rate which determines the share of profits (and hence wages). ${ }^{1}$

This does not mean that firms are able to fix their investment arbitrarily so that any share of wages will do. For any investment rate there is a determined level of the wage bill corresponding to the wage share. The firm must make sure that this level of the wage bill is sufficient to elicit the supply of labor needed to work with the investment which is achieved.

There is, however, another point of decision-making involved in the firm. The supply of work (in efficiency units) is a function of two variables: the number of workers and the supply of efficiency units per worker. The latter is a function of the wage rate. Thus for the profitmaximizing firm, for a given wage bill, the optimum labor supply will be achieved where the marginal cost of hiring an extra body of worker is exactly equal to the marginal cost of increasing the same number of labor units by increasing the wage rate of the existing workforce. This formal condition, of course, hides a number of factors which will affect the employer's choice. This includes institutional factors like job security legislation, union pressures etc., as well as economic variables affecting the relationship between the decision makers in the firm and their employees. ${ }^{2}$ If, for example, the power of 'insiders' in the workforce is strong, employers might be induced to locate on a higher point of the wage-efficiency' curve with a high wage per man

\footnotetext{
${ }^{1}$ See e.g., Eichner (1973). The author notes the affinity of the theoretical tradition to the empirical literature which has found from surveys of business pricing decisions that firms set prices on the basis of the "cost plus' concept. The 'plus' margin is in its turn set by the necessity to generate the profit share which finances the investment ratio. The affinity of these ideas to the Kalecki models of the firm have been stressed by Asimakopoulos (1971) among others.

${ }^{2}$ See Mazumdar (2003) for a more extended discussion of the labor market theories relevant to this set of decisions.
} 
and a high rate of supply of efficiency units. A similar situation might arise if job security laws make employers wary of the cost of employing a large body of workers which might be difficult to lay off. The employer's decision about the wage per man (determined within the constraints just mentioned) yields both the supply of work units per man and the wage cost per work unit.

The wage cost per efficiency unit of labor thus determined is one of several key variables which will influence the choice of technique for the investment to be undertaken. The latter in its turn determines the value added for the planned input of capital and labor. In full equilibrium the value added must be sufficient to support both the wage bill for the supply of labor units needed and the profit share to finance the investment planned. Thus the decision about the level of wages fixed and the investment rate are interrelated and must be consistent with each other. (see the Appendices 2 and 3 for an elaboration of the mechanics of the general equilibrium).

\section{. The Cyclical Predictions of the Model}

It is generally accepted in the economic literature that the rate of investment of the firm is very sensitive to expectations of market trends. This sensitivity to the perception of the future by entrepreneurs makes the investment ratio follow a typically cyclical pattern. Since the share of wages in our theory is ultimately determined by the investment ratio, it will have a cyclical pattern - though it would be anti-cyclical. The investment ratio increases in periods of optimism and thus the share of wages (and in our model $\alpha$ ) falls. This has the effect ceteris paribus of reducing the value of employment elasticity

Consider now the second labor market variable: the wage-employment trade-off. It has been recognized increasingly in modern labor economics that labor is also a quasi-fixed factor. We have discussed above that entrepreneurs have the option of increasing the flow of labor units either by hiring more workers, or by eliciting more work-units from the existing workforce by increasing the wage per worker. In many economies including India, a distinction has to be made between the permanent core of workers and contract labor of various types. The firm operates with at least a core body of tenured workers whose size is slow to respond to changes in the current demand for labor. This is because the cost of hiring-and-firing of 'permanent' workers is significant. Like the stock of fixed investment the firm's stock of the 'permanent' workers is built up more on their perception of expected demand. If current demand deviates from the expected demand, firms adjust the labor input for the period in question by varying the flow of labor units per worker rather than the stock of labor. They are able to do so principally because of the wage-efficiency mechanism making the flow of labor per worker an (increasing) function of the wage per worker. If expectations are buoyant firms would build up 
the stock of labor, and there would be less concern with an increase in wage per worker to elicit a larger inflow of labor units per worker. This will ceteris paribus tilt the wage-employment tradeof towards employment increase. Conversely, when there is a downward trend in expected growth, firms would tend to be more inclined to reduce the size of their labor force (through normal attrition of the quasi-fixed part and retrenchment of the non-tenured component) and meet their demand for labor input by increasing the wage per worker. Thus the trade-off would show a bias to wage growth.

It should be noted that wage increase in this kind of model is fuelled by three separate factors: (i) the inelasticity of supply of quasi-fixed labor of the requisite type to the individual firm; (ii) the upward institutional pressure on wages exerted by the firm-specific labor; and (iii0 the increase in wage needed to elicit a larger flow of labor per worker. In a recessionary period, with pessimistic expectations, presumably the factors (i) and (ii) will be weak or totally absent. But we can expect an increase in wage per worker due to the third factor. Taking all factors into account the net effect is more likely to be a slowdown in the rate of growth wages, but the wageemployment trade-off might still see a significant swing to wage growth if the relative fall in employment growth is high.

It is then seen that the cyclical behavior of the wage-employment trade-off is procyclical - the tilt to employment tends to increase in periods of optimistic expectations and decrease in times of gloomy prospects. Thus as far as the impact on employment elasticity is concerned the two elements of our decomposition model works in opposite directions with respect to economic cycles. In the upswing the wage share tends to fall leaving a smaller pie of value added to be taken in the form of either employment or wage in erase, but the trade-off leans towards a larger share for employment growth. The net result on employment elasticity depends on the relative strength of these two effects.

\section{III}

\section{Decomposition of the Factors Determining Employment Elasticity: Empirical Results}

The methodology of decomposition expounded in the last section is now applied to the time series for the organized manufacturing sector as given in the Annual Survey of Industry data set. The equation (1) is applied to growth rates separately for the four periods, which has been distinguished in section II. The results are presented below in Table III.1. Note that for each period the compound growth rates of the variables in the first five columns are calculated, and the 
value of the last variable alpha is calculated as a residual using equation (1). This is because, as explained the equation (1) must hold over a discrete period of time (in our case over the years covered by each of the four cycles). The value of $\alpha$ tends to adjust itself in each period to secure the equilibrium of the firm.

Table III.1. Proportionate growth rates of selected variables for four periods

\begin{tabular}{|l|c|c|c|c|c|c|c|c|c|}
\hline Period & $\begin{array}{c}\text { W } \\
\text { dot }\end{array}$ & $\mathbf{v}$ dot & L dot & $\mathbf{P}_{\mathbf{p}}$ dot & $\mathbf{P}_{\mathbf{c}}$ dot & Alpha & $\begin{array}{c}\text { Output } \\
\text { Effect }\end{array}$ & $\begin{array}{c}\text { Price } \\
\text { Effect }\end{array}$ & $\begin{array}{c}\text { Employment } \\
\text { Elasticity }\end{array}$ \\
\hline I (1974-80) & 2.63 & 3.99 & 3.95 & 7.10 & 4.72 & 1.02 & 4.07 & 2.52 & 0.99 \\
\hline II(1980-86) & 3.51 & 6.31 & -1.01 & 6.32 & 8.91 & 0.90 & 5.68 & -3.20 & -0.16 \\
\hline III(1986-96) & 1.83 & 10.65 & 3.54 & 9.10 & 9.56 & 0.76 & 8.10 & -2.68 & 0.33 \\
\hline IV(1996-02) & 0.88 & 1.75 & -2.74 & 3.07 & 6.92 & 1.11 & 1.93 & -3.53 & -1.42 \\
\hline
\end{tabular}

Note: The values of growth rates are compound rates. Alpha is calculated as a residual using the decomposition equation. The output and price effects are also calculated from the equation as defined..

We can see at once the enormous differences in employment elasticities - just about unity in the first period, turning strongly negative in the second period, and recovering to a value of just over 0.3 in the last period. In the last period post-reform years the employment elasticity has turned negative in amore substantial way than before, even as the output growth has faltered.

Period I can be considered to be the period of 'benign' growth in terms of the variables treated in our analysis. The economy experienced a moderately high rate of output growth at around 4 per cent per annum. This was, however, supplemented by a favorable trend in the producer prices relative to consumer prices. Since the value of Alpha was just over unity, the share of wages in gross value added grew at the same rate as output, so that in terms of real wage bill the growth rate was over 6 per cent per annum, including the real output growth plus the relative increase in producer prices. It is seen from Table III.1 that this growing cake was shared between wage growth and employment growth, with the latter taking the lead with the more substantial share of the wage bill growth.

The subsequent periods register major deviations from this standard. Of the non-labor market variables the trend in the DRER over all the three succeeding periods is a significant difference. The trend turned negative after the 'benign' first period, and quantitatively it was in all periods a significant 'leakage' from the growth in the real output. This can be seen by comparing the magnitudes in the column of the 'price effect' with those in the column headed 'v dot'. This adverse trend in the domestic terms of trade against manufactured products must be considered to be a major factor tending to dampen the value of employment elasticity after the first period of 
our study. The macro-economic factors causing this shift in the trend of this variable will be considered further in our subsequent discussion.

While this factor was a persistent negative influence on all the three periods, the cyclical swings in employment elasticity were the net result of the way the actual magnitudes of the two labor market variables worked out in these periods. Period II has been called the period of 'jobless growth' in India. In spite of a healthy rate of growth of output the employment elasticity turned negative (employment actually fell). It can be seen from Table III.1 that this was largely because of the large shift to wage growth in the wage-employment trade-off. The period of benign growth preceding it had seen an accumulation of excess labor in manufacturing, driven in part by the policies of government in alliance with a trade union movement biased to the policy of expanding ad protecting employment in the formal sector. When the dominance of this institutional support in favor those already in employment eased employers responded by policies which met the demand for labor by eking out more efficiency units of labor from a reduced stock.

The succeeding two periods of boom and slump saw working out of the labor market variables much as had been predicted in our theoretical discussion in the last section. In the upswing of the post reform years of Period III the uplift in the investment ratio resulted in a sharp reduction of the share of wages (a drastic reduction of $\alpha$ ). This would have pushed employment elasticity to further lower levels. But it was overshadowed by a tilt in the wageemployment trade-off to employment growth, as employers buoyed up by optimistic expectations and an erosion of the excess stock of labor from the last period, sought to build up their labor complement. The net result was a positive if low value of employment elasticity. The downswing of Period IV saw a large recovery of the value $\alpha$ and the wage share as the investment ratio slumped, but again it was swamped by the drastic shift in the wage-employment trade-off, this time against employment growth in line with our a priori expectations, and we see a significant negative employment elasticity for the period.

We shall now add short notes on each of the three periods II-IV elaborating on the economic and institutional factors influencing the value of employment elasticity as outlined in the last par. The trend decrease in the domestic terms of trade will be discussed at the end if this section, together with its policy implications.

\section{The Period of Jobless Growth 1980-86}

The spectacular fall in employment elasticity in the second period, extending from the end of the seventies to $1985-86$, is to a major extent due to the tilt in the trade-off to wage growth It has been ascribed to institutional factors emanating from trade unions pushing up wage rates 
(Hanson and Lieberman, World Bank Country Report 1989). But it can be seen from Table III.1 that although there was some increase in the rate of real wage growth (in constant consumer prices) in Period II, much larger part of the increase of product wage (in constant producer prices) was because of the sharp increase of the rate of growth of consumer prices relative to producer prices (or the domestic real exchange rate, DRER) Ajit Ghose (1994), in fact, pointed to the increase in the DRER as the crucial factor in the rise in capital intensity in industry, which slowed down employment increase. The increase of DRER was in turn a consequence of the abandoning of government policies to fix the price of food at low levels.

The impact of relative price changes meant was that although the real output growth increased somewhat in Period II, the growth rate of the real wage bill which could support wage and employment growth was drastically reduced below the level of Period I (from 6.59 to 2.46 as given in Table III.1). The fact that the real wage growth (in constant consumer prices) did not fall but actually increased somewhat in response, is prima facie evidence of the wage-employment trade-off being tilted in favor of the wage of those already in employment. Detailed examination of labor market institutions in this period, however, casts serious doubt on the hypothesis if his tilt was mostly or even primarily due to enhanced trade union power.

\section{Reshaping of Labor Institutions.}

As already mentioned this period saw the 'attitudinal' change to private business in Indian policy making. One aspect of this was the withdrawal of virtually automatic state support fro the large All-India trade unions which had been dominating industrial relations in the organized sector with the help of the major political parties. This attitudinal change was nowhere more prominently seen than in the Textile strikes of Bombay and Ahmedabad at the beginning of the eighties.

The power exerted by large-scale industry wide unions, often backed by political parties, and sometimes supported by the government in power, was seriously challenged in the early eighties by the owners of large factories in the older industries -which were rapidly becoming uncompetitive. The confrontation led to a large-scale closure of the mills, and after a long period of many months of lock-out, job loss without compensation on a fairly extensive scale. This major event saw a turning point in industrial relations in the large-scale manufacturing sector. Uchikkawa writes:

"The phenomenon reduced the incentive of workers to join labor unions. Membership of workers' unions including the service sector decreased from 8.18 million in 1986-7 to 5.61 million in 1996-7. Closure of many mills did big damage to the labor union movement 
because labor unions failed to protect job security." (Uchikawa 1993, p.38)

Uchikawa has produced a graph of the time series of job losses due to strikes and those due to lock-outs over the eighties and the nineties. His graph demonstrates that man-days lost by labor disputes dropped sharply during our second period, and for the first time fell below the level of jobs lost due to lock-outs. This altered relationship continued into the third period in the nineties (ibid, Figure 2, p. 39).

Moreover, as pointed out by Tirthankar Roy, there was shift in the nature of bargaining institutions. It began to be much more plant based than industry based. Industry wide unions were in decline throughout the eighties, making way for firm-specific bargaining. There is evidence for continued disputes at the plant level, sometimes spilling over into closures of factories. But such closures ceased to be industry- wide. It has been pointed out by several commentators that one of the major causes of the decline of the large industry-wide unions has been their de-linking with public sector undertakings, and the budgetary support they received from non-profit making firms financed by state budget deficits. "Indian labor regime is decisively changing. It seems to be changing from a pluralist regime, where unions can play a role in national politics via their dependent relationship with political groups, to a truly decentralized regime where unions have little or no relationship with political groups." (Roy, ibid, p.117)

It might seem odd that along with the decline in centralized union power which the last paragraphs suggest, there should have been an attempt by the government to strengthen job security legislation by the 1982 amendment to the Industrial Disputes Act which extended the protection to workers already in employment. The lower limit for the employment size of establishments beyond which permission had to be sought from the quasi-judicial authorities for any retrenchment was in fact reduced from 300 workers enunciated in the 1976 Industrial Disputes Act to 100 workers in the amendment of 1982. Fallon and Lucas (1993) used this amendment to 'explain' the reduction in employment elasticity in the eighties in their estimated labor demand function.. The conflicting trends can be reconciled in terms of the hypothesis that the government in the initial period of 'attitudinal' change was in effect pursuing a carrot-andstick policy. The withdrawal of automatic support for the All-India unions during large industrywide strikes was accompanied by the promise of extended support for job security if militancy were avoided.

Consistent with this stick-and-carrot policy employers seemed to have pursued a twoprong strategy of cutting down the size of a large union-supported laborforce but instead developing a core of smaller committed body of workers who could enjoy guaranteed employment. Moreover, the employment structure started to shift to the industry groups with 
lower labor intensity — electrical machinery, chemicals, transport equipment, rubber, plastic and petroleum products, non-electrical machinery etc.

As far as the wage growth reported in Table IV.1 is concerned several researchers, including Nagaraj (1993). Papola (1994), Bhalotra (1998) and Uchikawa (2002), have all pointed out the weakness in the analysis which refers only to number of workers rather than man-days worked. According to Uchikawa's latest research average annual working days in all manufacturing rose from 273 during the first period, to 300 days in the second period to 309 days during the third period. (Uchikawa's periods are fairly close to our first three periods distinguished in Table III.1). Thus the wage cost per man-hour of work did not increase at nearly the same rate as average earnings or average product wage per man.

Why did the number of man-hours per worker start to increase at the beginning of the second period? Uchikawa's explanation is that "the manufacturing sector had redundant workers in the late 1970s. Although growth rates of GVA (gross value added) declined, man-days increased during the recession period between 1978-9 and 1982-3." (ibid, p.38). Strong labor unions, still powerful at the end of the second period prevented retrenchment of redundant workers. Thus when industry recovered at the beginning of the eighties, there was enough 'surplus' labor available to increase the flow of labor in terms of hours of work required. The textile strike and its aftermath indicated above eased the way to elimination of the surplus labor which was being carried. The employer response to the changed climate of labor deployment in Indian manufacturing was to increase the flow of labor per worker from a reduced rationalized labor force.

\section{The Reform Period (1986-96)}

It has already been mentioned in our summary of the developments of Period III that the reform decade saw a jump in output growth to around 10 per cent. Another feature of the period was a sharp fall in the share of the wage as wages grew at only three-quarters of the rate of growth of output. But the rate of output growth was very high, and, furthermore, was augmented by the DRER swinging in favor of producer goods, so that the growth rate of the real wage billwhich could support ether wage or employment growth — was high at 5.37, up from 2.50 of the jobless growth period. The change in the wage-employment trade-off was also drastic, swinging substantially to employment rather wage growth. It might be tempting to suggest that both the tilt in the wage-employment trade-off towards employment growth and the decline in the share of wages in value added are due to the weakening of union power in the last period, which was discussed above. 
As far as the bias towards employment growth is concerned one of the elements in the story quite clearly is that the excess capacity of the laborforce, which might have been a legacy of the previous years, had been largely eliminated during the period of 'jobless growth'. With the strong output growth registered in this period it was necessary to increase the size of employment over time. Nevertheless, the relatively low employment elasticity suggests that employers might have been wary of the critical role of job security legislation. Not only was labor used more efficiently, employers in this period are widely reported to have used a variety of other methods of organizing production which helped to moderate the increase in 'permanent' employment. A major development discussed in the literature was the increasing use of sub-contracting. Ramaswami (2002) constructed an index of subcontracting by taking "the value of goods sold in the same condition as purchased plus the value of work done by concerns on material supplied"both sets of information given for the registered factories surveyed in the ASI. Although not covering all types of subcontracting, the data showed that 'subcontracting intensity' rose from 10 .in $1989-90$ to 12.3 per cent in $1994-5$, and the real value of subcontracting grew at a compound growth rate of 10.9 per cent -- at a faster rate than total output in manufacturing (ibid, table 4, p.135).

\section{The Investment Rate-Wage Share Nexus.}

A major factor which influenced employment elasticity—albeit in a downward direction - was the increased investment rate. Careful work by Uchikawa (2002) has shown that there was a sharp acceleration in gross investment in the first half of the nineties. The gross fixed capital stock in ASI industries increased at the rate of 10.1 per cent per annum at 1980-81 prices. A regression equation estimated for the time-series of capital stock showed that a multiplicative dummy for the post-1990 period was significant at the 5 per cent level, confirming the acceleration of investment after the economic reforms. The rate of growth of the capital stock was about three times the rate of growth of employment. There are several reasons for this spurt in investment, some of them having to do with the easing of control over the stock market which encouraged the corporate sector to shift their sources of finance from term lending to paid-up capital. The share of the latter rose suddenly from 7.1 per cent in 1992-3 to 29.6 in 1993-4. (Uchikawa).

The spurt in capital growth was clearly expectations of continued market expansion. This was the reason for the build-up of both capital stock and permanent labor by the manufacturing firms. The fact that the capital build-up was so much faster than the increase in the stock of labor shows that employers were still wary of labor as a potentially costly quasi-fixed factor, although 
improving the quality of production through more mechanized techniques might have been an additional motivation. This meant that although the trade-off shifted to employment growth employment elasticity was lower than it might have been.

There is another way that the spurt in investment rate depressed employment growth. As indicated the financing of investment shifted to retained profits to a considerable period ion this period. It has been suggested that a significant factor in the fall in the share of wages was the need to finance the increased investment rate form internal 'surplus' (see Appendix B for an elaboration and testing of this 'Kalecki-type' model). In terms of our decomposition equation the fall in the share of wages (or $\alpha$ in the equation) meant that a smaller chunk of the growing cake was available to support the wage bill growth. Thus employment growth was lower than otherwise.

\section{Decline in the growth rates of output and employment (1995-6 to 2001-2)}

The upswing in manufacture output tapered off in the second half of the nineties. From a highpoint of 14 per cent growth rate in 1995-6 the real value added (as well as the production index) have showed a steady decline. Over the period until 2001-2 the compound rate of growth has been a modest 1.75 per annum.

For manufacturing as a whole the rate of growth of real value added slumped to 1.75 per cent compared to 10.65 in the previous period. But the response of employment to the slump was even more drastic. Employment growth turned substantially negative: falling at the rate of 2.74 per cent per annum compared to the mere 1 per cent per annum during the earlier period of jobless growth in the eighties. This in spite of the rather sharp recovery of $\alpha$ to above unity, signifying an increase in wage share (and hence in wage bill growth) as the rate of investment slumped.

The drastic fall in employment elasticity was due to both factors isolated in our decomposition exercise: (i) the DRER turning against manufacture further as the producer price index increased at a much slower rate than the consumer price index; and (ii) the tilt in the wageemployment trade-off towards, once again, wage growth at the expense of employment growth.

Both these factors were important as indeed they were in the period of jobless growth. But looking at the magnitudes involved the quantitative importance of the DRER (price) factor was more important than the wage-employment trade-off.

The relative importance of the wage-employment trade-off can be quantified by noting the difference between $\mathrm{L}$ dot and $\mathrm{w}$ dot. A negative sign of the value signifies that there is a tilt towards wage growth, while a positive value indicates that employment growth is preferred. Thus 
other things being equal, a positive value of the first term would favor an increase in employment elasticity, while a negative value would signify that the bias towards wage growth reduces employment elasticity. The DRER effect is the difference between Pp dot and Pc dot. Given real output growth $\mathrm{v}$ dot, a negative value of the DRER indicates a leakage from the growing cake, which has to be shared between wage growth and employment growth: ceteris paribus it depresses employment elasticity. The quantitative importance of the two effects can be studied by comparing the difference [L dot minus $\mathrm{w}$ dot] with the difference $\left[\mathrm{P}_{\mathrm{p}} \operatorname{dot}\right.$ minus $\left.\mathrm{P}_{\mathrm{c}} \operatorname{dot}\right]$. The way these relative magnitudes varied as between the four periods of our study is given in Table IV.3

Table III.5 The relative importance of the wage-employment trade-off and the DRER effect

\begin{tabular}{|c|c|c|c|}
\hline Period & $\begin{array}{c}\text { L dot minus } \\
\text { W dot }\end{array}$ & $\begin{array}{c}\mathrm{P}_{\mathrm{p}} \text { dot minus } \\
\mathrm{Pc} \operatorname{dot}\end{array}$ & Employment Elasticity \\
\hline I 1974-80 & 1.32 & 2.38 & 0.99 \\
\hline II 1980-86 & -4.84 & -2.59 & -0.16 \\
\hline III 1986-96 & 1.71 & -0.46 & 0.33 \\
\hline IV 1996-2002 & -3.62 & -3.85 & -1.42 \\
\hline
\end{tabular}

It should be emphasized, however, that although the negative trend in the DRER was strong, the tilt in the wage-employment trade-off towards wage growth was also substantial - in fact a more important relative change compared to the previous period. 
The shift in the wage-employment trade-off: Labor market behavior.

An interpretation in terms of a strictly dynamic neo-classical model is very problematic. It will be recalled that in Period III for All-India while employment grew at 3.54 per cent per annum, the real wage increased at the rate of 1.83 . In the post-reform period IV when employment growth was significantly negative at -2.74 per cent per annum, real wage still increased at 0.88 per cent. The fall in the rate of growth of real wage with the decrease in employment growth might at first sight seem to be consistent with a neo-classical model in which the dynamic supply curve of labor is gently upward sloping. But the fact that wage growth still grows at nearly 1 per cent per annum even when employment is falling at the annual rate of 2.74 per cent is inherently implausible in strictly supply-and-demand terms. It is necessary to invoke one of several labor market forces which pushes the wage level upwards at a significant rate even when employment growth is zero or negative. Such factors include the following -which might operate singly or in combination: (i) an upgrading of labor might be going on with skill formation due to technological change; (ii) the efficiency-wage function so that the flow of labor units supplied per worker increases; and (iii) 'insider' power which keeps the wage increasing through time even when employment growth is negative.

All these types of wage behavior imply the existence of a firm-specific labor force which is a 'quasi-fixed' factor in the firm's production function. AS already mentioned, the firm operates with at least a core body of tenured workers whose size is slow to respond to changes in the current demand for labor. Like the stock of fixed investment the firm's stock of the 'permanent' workers is built up more on their perception of expected demand. If current demand deviates from the expected demand, firms adjust the labor input for the period in question by varying the flow of labor units per worker rather than the stock of labor. They are able to do so principally because of the wage-efficiency mechanism making the flow of labor per worker an (increasing) function of the wage per worker.

This hypothesis would seem to fit the different scenarios witnessed in the Indian manufacturing sector for the periods of reforms and the post-reform years - the Periods III and IV respectively of the analysis presented above. In the reform decade there was a general euphoria about the expansion of business in which the entrepreneurs participated with enthusiasm. It seems to have led to a rebuilding of the stock of labor which had been drawn down during the preceding decade of 'jobless growth'. The recession of the second half of the nineties, along with the adverse movement of the producer prices facing manufacturers, led to a revision of these expectations. It might have prompted a hurried attempt to reduce the permanent workforce, and 
possibly a greater use made of out-sourcing, which led to the substantial negative employment elasticity. The increase in wages slowed down relative to Period III but it was positive. Thus the wage-employment trade-off swung to wage growth.

The downward trend in the domestic terms of trade ${ }^{3}$

We have seen that the adverse movements of producer prices to consumer prices had a significant role in depressing the value of employment elasticity in manufacturing, and in fact producing negative values for this variable in Periods II and IV. The relative movement of prices, however, depends not only on labor market conditions but also on overall macroeconomic factors. For instance if real effective exchange rates appreciate or do not depreciate to maintain manufacturing competitiveness, the domestic terms of trade can be adversely affected. As Figure 3.3 (left panel) shows, this indeed happened since the mid1990s: real effective exchange rates stabilized and even appreciated slightly since then. This was associated with an adverse movement of produce prices relative to consumer prices. Econometric estimates show that, after controlling for time trends, there is robust relationship between real exchange rate appreciation and adverse movements in the domestic real exchange rates (Figure 3.3, right hand side panel), which in turn lowers employment elasticity. Thus, one policy implication will be to keep exchange rates competitive through guarding against inflation, especially of consumer goods. This in turn has implications for fiscal policy. Higher deficits, Government borrowing, and inflation tend to appreciate real exchange rates. If Government expenditure growth is directed disproportionately towards consumption - as has been the trend in India in the 1990s -- that will also turn the domestic real exchange rate against producers and discourage the growth of jobs. If Government policy raises food prices in an artificial manner that will also lower manufacturing elasticity.

\footnotetext{
${ }^{3}$ I am grateful to Ahmad Ahsan of the World Bank for providing the ideas and calculations for this subsection
} 
Figure III. 1: Changes in Real Effect Exchange Rates and Domestic Real Exchange Rates (Producer Prices to Consumer Prices)
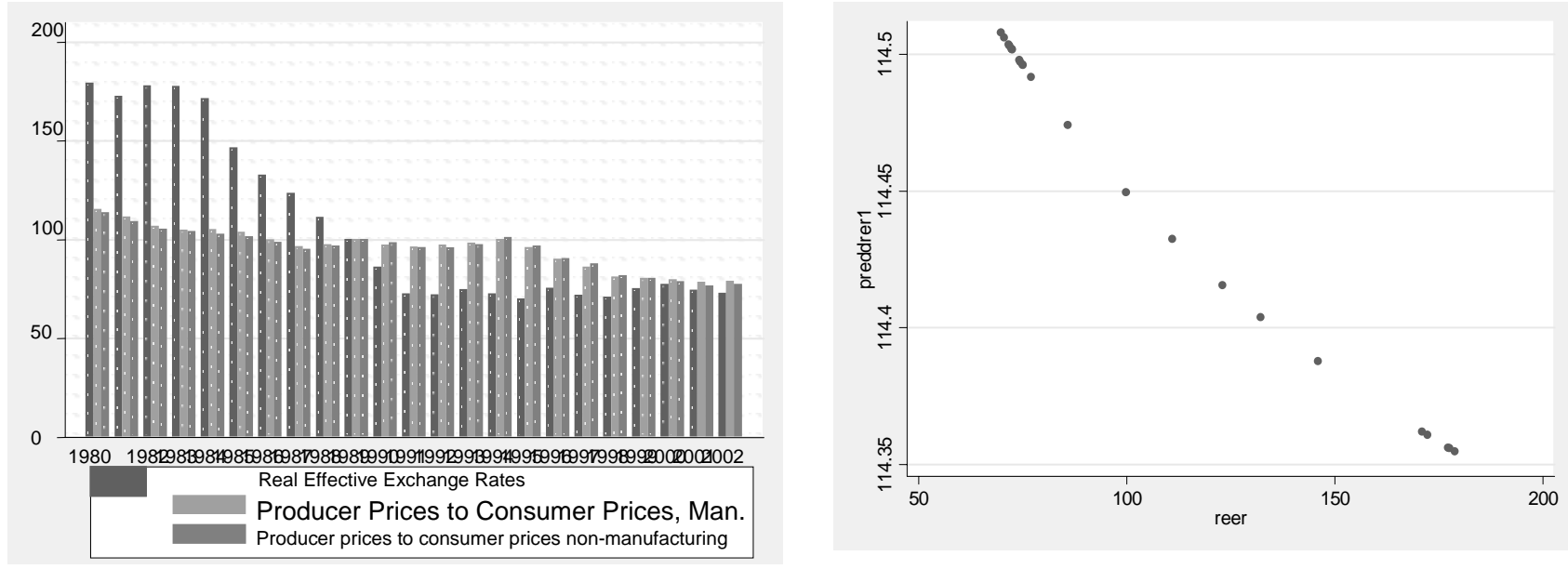

Source: Estimated from data on prices given in the Annual Abstract of Statistics (GOI and RBI data on real exchange rates. 
We have so far dealt with the whole of organized (formal) manufacturing as a single entity. It is now important to extend the story to cover some critical issues involving a more disaggregated view of this sector. These are: (i) the difference between the publicly and privately owned units in manufacturing; (ii) individual sub-sectors distinguished by key characteristics like technology and trade-orientation: and (iii) manufacturing establishments of different size-groups.

\section{Public and Private sub-sectors.}

The Public Sector was a significant part of organized manufacturing in Period I. The high employment elasticity observed in this period was at least partly due to the influence exerted by the All-India unions, with strong affiliation to political parties, in favor of expanding "good jobs" in the formal sector. Since the wage-gap was already very high in favor of the formal sector, the interest of unions was more in the direction of increasing its membership of the privileged workers - rather than the OECD type of bias towards the wage increase of "insiders".

The reform period saw a decline in the public sector as the state controlled pattern of manufacturing growth was gradually whittled down. The following table gives the results of the decomposition analysis separately for the public and private sector establishments in the ASI time series.

Table IV.1: Proportionate growth rates for the public and the private sectors, 1986-7 to 1994-5

\begin{tabular}{|c|c|c|c|c|c|c|c|c|c|}
\hline Sub-sector & w dot & $\mathbf{v ~ d o t}$ & L dot & $\mathbf{P}_{\mathbf{p}}$ dot & $\mathbf{P}_{\mathbf{c}}$ dot & Alpha & $\begin{array}{c}\text { Output } \\
\text { Effect }\end{array}$ & $\begin{array}{c}\text { Price } \\
\text { Effect }\end{array}$ & $\begin{array}{c}\text { Employment } \\
\text { Elasticity }\end{array}$ \\
\hline Public & 2.38 & 5.58 & -0.11 & 9.28 & 9,43 & 0.79 & 4.40 & -2.12 & -0.02 \\
\hline Private & 1.60 & 10.97 & 3.55 & 9.28 & 9.43 & 0.72 & 7.90 & -2.75 & 0.32 \\
\hline All Manufg. & 1.50 & 9.68 & 2.77 & 9.28 & 9,43 & 0.72 & 7.00 & -2.73 & 0.29 \\
\hline
\end{tabular}

Note: The figures for all manufacturing differ from those given in Table IV.1 because we could not include the high growth year of 1995-6 because of lack of data.

'Public' includes establishments wholly owned by sate and/or local governments as well as those owned jointly owned jointly with the private sector. Employment tin joint sector establishments was around 10 per cent of the total in all public manufacturing in 1987-8.The private sector variables are calculated as residuals and therefore include 'unspecified' units.

The data in Table IV.1 show the slower growth rate of output in the public sector undertakes, as well as the attempt to reduce over-manning. The relatively high growth rate of wages in this sub-sector probably is partly an attempt to reduce the excess capacity built up 
among the workers. As pointed out earlier the increase in wage per man-hour would probably be not as much. However, the broad conclusions arrived at above for all manufacturing, without making the public-private distinction, are not altered.

The Composition of Industry.

New technology and greater openness are the two characteristics of the reform period. Accordingly it is useful to classify the industries at the 2-digit level of the NIC classification in term of the dual characteristics of the level of technology, and exposure to the world markets. The latter in turn involves the degree of import penetration and or the proportion of output exported. We used the input-output table for the Indian economy constructed by the Planning Commission for 1991 to undertake such a classification. The results are given in Table IV.2.

Table IV.2: Classification of Industries by Technology level and Exposure to trade 1991

\begin{tabular}{|l|l|l|c|c|c|c|}
\hline $\begin{array}{l}\text { Technology Level } \\
\text { Plus Exposed ratio }\end{array}$ & NIC Code & $\begin{array}{l}\text { Import } \\
\text { Penetration }\end{array}$ & $\begin{array}{l}\text { Export } \\
\text { Ratio }\end{array}$ & $\begin{array}{l}\text { Exposed } \\
\text { Ratio }\end{array}$ & $\begin{array}{l}\text { Size of } \\
\text { Sector (\%) }\end{array}$ & $\begin{array}{l}\text { Sector } \\
\text { Code }\end{array}$ \\
\hline High Exposed & $30+35$ to 37 & 29.50 & 6.05 & 33.76 & 31.77 & 1 \\
\hline Medium Domestic & 31 to 34 & 11.08 & 3.83 & 14.48 & 23.86 & $2 \mathrm{a}$ \\
\hline Medium Exposed & 38 & 25.31 & 28.37 & 46.50 & 5.46 & $2 \mathrm{~b}$ \\
\hline Low Domestic & $20,22,27$ & 1.35 & 2.98 & 4.29 & 15.55 & $3 \mathrm{a}$ \\
\hline Low Exposed & 23 to26; 28+29 & 2.73 & 15.79 & 18.09 & 23.35 & $3 \mathrm{~b}$ \\
\hline & All & 14.30 & 8.54 & 21.62 & 100.00 & \\
\hline
\end{tabular}

Definitions:

\begin{tabular}{|ll|}
\hline Import Penetration $=$ & $($ Value of Import $) /($ Value of Output - Value of Export $) * 100$ \\
\hline Export ratio $=$ & (Value of Export $/($ Value of Output $) * 100$ \\
\hline Exposed Ratio $=$ & (Value of Import + Value of Export $) /($ Value of Output $) * 100$ \\
\hline
\end{tabular}

Source: Planning Commission 60×60 Input-output table, 1991 .

NIC codes: 30: Basic Chemicals and chemical products

35-36: Machinery and Equipment other than Transport equipment.

37: Transport Equipments and parts.

31: Rubber, Plastic, Petroleum \& Coal products

32: Non-metallic Mineral products

33: Basic Metals and Alloys Industries

34: Metal Products \& parts except machinery

38: Other Manufacturing Industries

23: Cotton textiles

24: Wool, silk and man-made fiber textiles

25: Manufacture of Jute and other vegetable fiber

26: Textile products including Wearing Apparel.

28: Paper and paper products

20-21: Food products 
22: Beverages, Tobacco \& related products

27: Wood and wood products

It is seen that in 1991 the high technology sub-sectors had not yet started to play a significant role in exports. Rather trade liberalization measures allowed some of these groups to establish themselves with a sizable "import penetration" ratio (sector 1 in the table). The industries classified as using medium-low technology were of two types: NIC groups 31-34 (code 2a) was domestically oriented, although making use of a not insignificant proportion of imports. But a group had emerged (group 38), consisting a variety of new 'other manufacturing' which exported a substantial proportion of its output, and also had a high import penetration. This was then the sub-sector with the highest degree of globalization (our 'exposure ratio'). However, its over-all importance in terms of the total share in value added in all manufacturing was only around 5 per cent in 1991. Low technology manufacturing, as is to be expected, had very low import penetration. But one sub-group (3b) had a significant export ratio, and indeed accounted for nearly a quarter of the total output of manufacturing. These included textiles and textile products, paper and lather products. Industry groups 20, 22 and 27-food and beverages and wood products-- were the truly domestic industries at this date, with a share of 15 per cent of total manufacturing.

It might be of some interest to look at the trends in the key variables studied above for all variables, separately for the industry groups just distinguished. The data are reproduced in Table IV.3.

Table IV.3: Trends in selected variables by industry groups 1986-7 to 1996-7.

\begin{tabular}{|c|c|c|c|c|c|c|c|}
\hline Period III & $\begin{array}{c}\text { Industry } \\
\text { group }\end{array}$ & W dot & V dot & L dot & Pp dot & Pc dot & Alpha \\
\hline & $\mathbf{1}$ & 1.58 & 12.83 & 4.73 & 8.49 & 9.56 & 0.74 \\
\hline & 2a & 2.38 & 11.22 & 3.01 & 8.71 & 9.56 & 0.75 \\
\hline & 2b & 0.44 & 16.57 & 7.54 & 5.27 & 9.56 & 0.80 \\
\hline & 3a & 2.51 & 7.58 & 3.27 & 9.79 & 9.56 & 0.88 \\
\hline & 3b & 0.66 & 6.86 & 2.75 & 10.40 & 9.56 & 0.75 \\
\hline
\end{tabular}

The first point to note is that there is a clear difference in the rates of growth in industry groups of different levels of technology. The higher technology sub-groups-- 1, 2a and 2b-had a significantly higher rate of output growth. The group of "new" industries identified above (2b) as leading the charge in export markets, suffered from a relatively lower trend in producer prices (compared to the trend in consumer prices), so that some of its growth was 'lost' in the declining 
terms of trade. Both the low technology industry groups - the more 'exposed' as well as the less so - had a decidedly lower rate of growth.

Turning to labor market outcomes, domestically oriented low technology sub-group (3a) seems to have suffered the least from the adverse price (DRER) effect, and labor's share declined the least in this industry group. Thus the wage bill growth was nearly on par with output growth. But the tilt to employment growth as against wage growth was the least pronounced in this group. A reasonable hypothesis is that these older domestically oriented industries continued to experience some of the old power of 'insiders'. Thus in spite of the rate of output growth being the second lowest, the growth rate of real wages was highest in this group.

It is, however, remarkable that all three sub-groups with the highest 'exposure ratios' groups $1,2 \mathrm{~b}$ and $3 \mathrm{~b}$ - had the lowest rate of growth of real wages. In the two exports oriented groups, $2 \mathrm{~b}$ and $3 \mathrm{~b}$ in fact the growth rate of real wages was barely positive. The wageemployment trade-off had in fact swung heavily in favor of employment growth even as the share of wages declined significantly. We can conclude with some confidence that, if the aim of liberalization had been to promote labor-intensive growth and reduce the power of those already in employment, our first cut at the evidence shows that the policy certainly succeeded in its objectives to some extent.

\section{Changes in the Size structure of Industry}

A major development in the reform period has been that, along with the change in labor institutions mentioned in the last paragraph, there has been a distinct shift of production and employment to small-medium enterprises (SMEs), reducing the role of large factories in the manufacturing sector. This development has important implications for economic welfare generally, and on employment elasticity in particular. Table IV.3 gives the relevant data documenting the change.

Table IV.3: Employment and Gross Value Added by Size Classes of Factories

\begin{tabular}{|l|c|c|c|c|c|}
\hline & \multicolumn{3}{|c|}{ Distribution of Employment (\%) } & \multicolumn{2}{c|}{ Annual Growth Rate (\%) } \\
\hline Size Group & $1984-85$ & $1989-90$ & $1994-95$ & $1984-89$ & $1989-94$ \\
\hline $10-49$ & 15.07 & 18.09 & 17.37 & 4.36 & 1.31 \\
\hline $50-199$ & 19.84 & 24.25 & 26.19 & 4.74 & 3.73 \\
\hline $200-499$ & 13.99 & 15.68 & 16.40 & 2.94 & 3.07 \\
\hline $500-999$ & 12.95 & 12.88 & 15.34 & 0.52 & 5.77 \\
\hline $1000 \&$ above & 38.15 & 29.11 & 24.70 & -4.68 & -1.16 \\
\hline Total & 100.00 & 100.00 & 100.00 & 0.62 & 2.14 \\
\hline & \multicolumn{3}{|c|}{ Distribution of GVA (\%) } & Annual Growth Rate (\%) \\
\hline Size Group & $1984-85$ & $1989-90$ & $1994-95$ & $1984-89$ & $1989-94$ \\
\hline
\end{tabular}




\begin{tabular}{|l|c|c|c|c|c|}
\hline $10-49$ & 8.34 & 9.14 & 9.06 & 9.35 & 8.59 \\
\hline $50-199$ & 13.20 & 16.03 & 17.69 & 12.02 & 10.60 \\
\hline $200-499$ & 14.93 & 16.77 & 18.74 & 10.44 & 11.14 \\
\hline $500-999$ & 17.15 & 17.44 & 21.28 & 8.53 & 13.49 \\
\hline $1000 \&$ above & 46.38 & 40.62 & 33.22 & 4.76 & 5.16 \\
\hline Total & 100.00 & 100.00 & 100.00 & 7.76 & 9.03 \\
\hline
\end{tabular}

Note: The total mentioned here is total of five size groups mentioned above. But it excludes factories in the $\quad 0-9$ employment size group. So growth rates of the total will not match with manufacturing sector's growth rates.

These figures show that size groups with 50-999 employees increased their share in employment and gross value added while the size group of $1000 \&$ above employees reduced their share. In the late eighties the SMEs in the size groups 50-199 and 200-499 were the most dynamic groups, and in the nineties the group 500-999 joined them in having a relatively high rate of growth. Employment in the largest size was particularly affected, falling at the rate of 4.68 per cent per annum in the 1984-89, and of 1.16 per cent in the first half of the nineties, while the other groups had significant positive rates of growth.

How much was this change in the size-structure related to the change in the composition of industry noted in the paragraphs above? We crossed the five-group classification if industries given in Table III.2 above with the five size groups of Table IV.1 and noted the cells showing substantial increase or decrease (more than 5 per cent) in its share. The results are given in Table IV.2.

Table IV.2: Size classes with substantial change in the share of total employment by industry groups, 1984-5 to 1994-5.

\begin{tabular}{|c|c|c|}
\hline Industry group code & Substantial gain & Substantial fall \\
\hline 1 & $50-199 ; 200-499$ & $1000+(13 \%)$ \\
\hline $2 \mathrm{a}$ & $10-49$ & $1000+(8 \%)$ \\
\hline $2 \mathrm{~b}$ & $50-199$ & $10-49(7 \%)$ \\
\hline $3 \mathrm{a}$ & $50-199 ; 200-499$ & $1000+(24 \%)$ \\
\hline 3b & $50-199$ & $1000+(6 \%)$ \\
\hline
\end{tabular}

Note: Industry codes as defined fir Table III.2.

It is seen that the reduction in the relative importance of the very large firms was generally across the board, although the low tech, somewhat export oriented group (3a) seems to have had the most spectacular loss in this size group. Only the group of miscellaneous industries rapidly expanding in the export markets $(2 \mathrm{~b})$ might have increased its average employment size as the share of 50-199 enterprises increased at the expense of the very small ones. Were there significant differences in labour market outcomes in 
different size classes of enterprises? The decomposition analysis, used above for all manufacturing, was applied separately for the five size groups distinguished. The results are set out in Table IV.3.

Table IV. 3 Decomposition results by size-classes of factories, 1984-5 to 1994-5

\begin{tabular}{|l|c|c|c|c|c|c|c|c|c|}
\hline Size Groups & $\dot{W}$ & $\dot{V}$ & $\dot{L}$ & $\begin{array}{c}\dot{P} \\
p\end{array}$ & $\underset{c}{\dot{P}}$ & $\alpha$ & $\begin{array}{c}\text { Price } \\
\text { Effect }\end{array}$ & $\begin{array}{c}\text { Output } \\
\text { Effect }\end{array}$ & $\begin{array}{c}\text { Employment } \\
\text { Elasticity }\end{array}$ \\
\hline $10-49$ & 3.179 & 8.893 & 2.534 & 8.777 & 9.348 & 0.850 & -1.888 & 7.599 & 0.285 \\
\hline $50-199$ & 2.905 & 11.467 & 6.637 & 8.777 & 9.294 & 0.840 & -1.921 & 9.632 & 0.579 \\
\hline $200-499$ & 2.337 & 11.553 & 3.493 & 8.777 & 9.303 & 0.750 & -2.720 & 8.665 & 0.302 \\
\hline $500-999$ & 1.344 & 10.943 & 2.967 & 8.243 & 9.295 & 0.710 & -3.442 & 7.770 & 0.271 \\
\hline $1000 \&$ above & 1.883 & 5.027 & -1.554 & 8.318 & 9.295 & 0.710 & -3.389 & 3.569 & -0.309 \\
\hline
\end{tabular}

Source: Own Calculations from data tapes of ASI

The rate of growth of real output was somewhat low in the smallest size group though not so low as the largest size group $(1000+)$, but all the other three SME groups with employment size ranging from 50 to 500 workers registered a remarkably high rate of output growth. It is seen that, with the sole exception of the smallest size group 1049 , the employment elasticity ( $L$ divided by $v$ ) decreases as the size class increases. It is then clear that the redistribution of output to small and medium enterprises from the largest size group (though not to the smallest) was one of the factors which help bump up the over-all employment elasticity in the reform period.

The DRER effect in terms of the differences in the rates of growth of producer and consumer prices is of minor importance in the over-all differences in the wageemployment outcome by size groups. It should be apparent that the differences in employment elasticity by size-groups are the joint outcome of different values of $\alpha$ and the wage-employment trade-off.

(a) The most striking result in the above table is the inverse relationship of $\alpha$ with the size classes - with exception of the largest size class, for which $\alpha$ stayed at the same value as the next lower size group. The major conclusion reached earlier about the third period for manufacturing as a whole was that. the reduction in wage elasticity with respect to value added - which implies a fall in the share of wages - was due to the increase in investment rate. In the extended econometric exercise reported in Appendix B we get the result that the inverse relationship of $\alpha$ with the investment rate is confirmed (after allowing for variations in capital productivity) — but $\alpha$ still falls 
monotonically with the firm-size groups. This is most likely due to capital intensity increasing with firm size.

(b) The wage-employment trade-off did not have such a clear pattern. But we can read from the table it favored wage growth for the smallest (10-49) and the largest (1000+) groups, employment growth actually being negative in the latter case. In all other size groups the employment growth rate was substantially higher than wage growth. The bias to wage growth relative to employment growth in the smallest and the largest size-groups have probably different explanations. The wage growth in the 10-49 size group is likely to have been a supply-side phenomenon as the period saw a faster increase in the alternative earnings of labor in the unorganized (informal) sector. For the very large firms (1000+) the tilt o wage growth reflects the continued effort on the part of employers to trim the number of permanent workers and increase the efficiency of the smaller body of the workforce through higher wages per worker. 


\section{Conclusions}

The review of the Indian experience in formal manufacturing over the last quarter of the century revealed the enormous fluctuation in employment elasticity from period to period. Starting with the period of 'benign' growth in the last half of the ' $70 \mathrm{~s}$, when employment elasticity was nearly unity, employment growth turned somewhat negative in the period of 'jobless growth in the ' 80 s. It picked up to a reasonable, but not unduly high, value of 0.33 during the reform period, when output growth was also high. But it slumped badly to a substantial negative figure in the latest post-reform years of 1996-2001 when output growth also stumbled.

We have learnt from the decomposition model that there are three sets of factors affecting employment elasticity, given the rate of growth of real value added: (i) the trend in the share of wages as measured by our $\alpha$; (ii) the wage-employment trade-off; and (iii) the trend in the domestic real exchange rate or the relative movement over time of the producer price index relative to the consumer price index. The last variable is, for the present analysis, more in the nature of an exogenous factor which defines the rate of growth of the wage bill in consumer prices (which is of relevance to the workers' welfare). The first two are labor market variables. At first sight they might both seem be related to the strength or weakness of workers' organization like trade unions, but this would be overlooking the different decision making processes at the firm level which affect the two variables.

The model has a strong suggestion that the employment elasticity resulting from the interaction of these factors will have a cyclical pattern. This is because expectations about future market conditions play a critical role in the model with two factors -capital and labor, which are both quasi-fixed. The model enables us to decompose the determinants of employment elasticity into these three key factors. It is applied to the case of formal manufacturing in India over the period $1974-75$ to $2001-02$.

As predicted the employment elasticity does show the cyclical pattern-and four phases are distinguished. They correspond reasonably way to different periods of the recent political economy of Indian development culminating in the reform period (1986-96) and the immediate post-reform period of 1996-2002. The relative importance of the three key factors in the fluctuating trend of the employment elasticity over the four periods are discussed - particularly in terms of the changes in labor market institutions.

While the illustrative case of India of interesting itself some of the findings are of general importance for many economies in the globalizing world. 
First, a strong finding was that the downward trend in the DRER has been persistent for the last two decades of the past century. The DRER is of course closely related to the terms of trade of manufactured products to that of primary commodities (particularly cereals). This turning of the terms of trade against the latter has been noted in the literature (cf. Kaplinsky for a recent contribution). In the Indian case desegregation of the manufacturing sector shows that the competitive pressure facing manufacturing producers in the domestic market after liberalization might have as much to do with downward trend of the DRER (which seemed to have gathered momentum in the post-reform period) as the trend in prices of the growing manufactured exports. Second: the close relationship between the investment rate and the share of wages (or with $\alpha$ ) is established in the Indian case and we have provided independent evidence of the importance of growing importance of internal finance to the boom in investment in the reform period. Although economies would differ in the importance of this connection, it is probably of general importance, and would indeed be found to be of importance in the determination of employment elasticity in most economies.

Third: wage-employment trade-off is a key determinant. It is influence partly by employer perception of the expected demand for labor relative to the perceived cost of altering the complement of permanent workers. On the other hand, institutions on the labor side will play an important role the decisions about this trade-off. Some of the theoretical issues as well as possible empirical differences between regions of the world were discussed in Mazumdar (2003). In the present paper the Indian case illustrates how difficult it might be to reduce the perception of labor as a quasi-fixed factor of perception once it has been established in the industrial culture. Our discussion of the reform period in India shoed that important changes have been made in the direction of slackening the rigidity in the labor market of the formal sector, both in the way labor unions operated and the job security legislation was being implemented. But the results do suggest that employers continue to be wary of the fixed costs of increasing their complement of permanent labor, and the downward revision of expectations in the post-reform years of 19962002 is seen to have had a strong effect in tilting the trade-off to wage growth relative to employment growth.

In the last section of the paper we looked at some selected issues for disaggregated subsectors of formal manufacturing. The analysis was applied, for example, separately to groups of industry classified by trade exposure and technology. An important result is that while the elasticity of employment fell in all categories in the post liberalization period (period IV) compared to the previous one, revealingly it fell most in the low technology exposed industries 
and the least in high technology domestic industry. Sectors more exposed to trade have tended to have higher employment elasticity in both periods but it also suffered a decline in elasticity in the post reform years. However, while employment elasticity declined across the board, the reasons for the decline differ according to the degree of exposure to trade. In the more exposed industries, the choice of techniques that tilted towards higher wages instead of employment which is consistent with firms adjusting to raise skills and productivity of workers - has been the more important factor behind reducing elasticity. In the less exposed domestic industries, the domestic real exchange rate effect - the increase in consumer prices relative to producer prices has been more important one. 


\section{REFERENCES}

Asimakopoulos, M. (1971), 'The Determinants of Investment in Keynes's Model', Canadian Journal of Economics, Vol. 4, No. 3, pp.382-388.

Bhalotra, Sonia R.. 1998. 'The Puzzle of Jobless Growth in Indian Manufacturing', Oxford Bulletin of Economics and Statistics vol. 60 (1), pp.5-32.

Eichner, Alfred S. (1973) 'A Theory of the Determination of the Mark-up' Economic Journal, 83 , no. 332, 1184-1200.

Fallon, P and R E B Lucas. (1993). "Job Security Regulations and the Dynamic Demand of Industrial Labor in India and Zimbabwe', Journal of Development Economics, vol 40, pp. 241-75.

Ghose, Ajit K.(1994), 'Employment in Organized Manufacturing in India', Indian Journal of Labor Economics, Vol, 37, no. 2, April-June, pp.141-62.

(2003). 'Jobs and Income in a Globalizing World, ILO, Geneva.

Government of India (2002). Report of the Special Group on Targeting Ten Million Employment Opportunities per Year over th3 $10^{\text {th }}$ Plan Period. Reproduced in Planning Commission Reports on Labor and Employment, Academic Foundation, New Delhi

Kaplinsky, Raphael (2006) 'Revisiting the Revisted Terms of Trade: Will China Make a Difference?' World Development, 34, 6, pp 981-995.

Mazumdar, Dipak. (2003). 'Trends in Employment and the Employment Elasticity in Manufacturing, 1971-92: An International Comparison', Cambridge Journal of Economics, 27,4, 563-582

(2005) 'The Employment Elasticity in Manufacturing A Rejoinder' Cambridge Journal of Economics, 29, 4, 665-667

(with Sandip Sarkar) (2006) 'Employment Elasticity in Organized Manufacturing in India' Paper Presented at a Conference on 'India: Meeting the Employment Challenge', Institute for Human Development (supported by the World Bank), July 27-29, New Delhi

Morawetz, D. (1974). 'Employment Implications of Industrialization in Developing Countries', Economic Journal, vol. 84, no. 335, pp 491-542.

Nagraj, R. (1994), 'Employment and Wages in Manufacturing Industries: Trends, Hypotheses and Evidence', Economic and Political Weekly, vol. 29, no. 4, January 22, pp. 177-86.

Papola, T.S. (1992). 'Labour Institutions and Economic Development: The Case of Indian Industrialization' in Papola, T.S. and Rodgers, G. (eds), Labour Institutions and Economic Development in India, IILS Research Series no. 97, ILO, Geneva. 
Roy, Tirthankar (2002). 'Social Costs of Reforms: A study of job loss with special reference to declining industries in 1990-98” Chapter in Uchikawa (2002) pp. 99-126.

Uchikawa, Shuji, Ed. (2002). Economic Reforms and Industrial Structure in India. Manohar, New Delhi

Uchikawa, Shuji, Ed. (2003) Labour Market and Institutions in India: 1990s and Beyond. Institute of Developing Economies, Tokyo.

Uchikawa, U. (2001) 'Investment Boom and Underutilisation of Capacity in the 1990s', Economic and Political Weekly, August 25.

World Bank, (1989), India: Poverty, Employment and Social Services: A World Bank Country Study, World Bank, Washington D.C. 


\section{APPENDIX 1}

\section{The Decomposition Model Used in the Paper}

The following are the variables used:

$$
\begin{aligned}
& \mathrm{w}=\text { real wage ( average earnings per worker) } \\
& \mathrm{S}_{\mathrm{w}}=\text { wage bill (in current prices) } \\
& \mathrm{V}=\text { value added (in current prices) } \\
& \mathrm{v}=\text { value added (in constant prices) } \\
& \mathrm{L}=\text { employment } \\
& \mathrm{P}_{\mathrm{p}}=\text { index of producer prices } \\
& \mathrm{P}_{\mathrm{c}}=\text { index of consumer prices }
\end{aligned}
$$

The relationship defining the movement of the wage bill with respect to value added over time is specified by the following equation:

$$
\mathrm{S}_{\mathrm{w}}=\mathrm{A} \mathrm{V}^{\alpha}
$$

$\mathrm{A}$ is a positive constant less than unity, determined by the base-year share of wages;

$\alpha$ is a technological and behavioral parameter which is assumed to remain constant over the period under consideration. However, it can take any positive value and would generally vary from one period to another, even in the same economy another depending on the factors determining the share of wages over time. If it has a value of unity, the share of wages remains constant. A variable written with a dot on top (') represents the proportionate rate of change of the variable concerned.

Note that from (1)

$$
\dot{S}_{w}=\alpha \dot{V}
$$

where $\mathrm{A}$ is a positive constant less than unity, determined by the base-year share of wages.

We can then write the equation for the real wage growth as:

$$
\begin{aligned}
& \dot{w}=\dot{S}_{w}-\dot{L}-\dot{P}_{\mathrm{c}} \\
& =\alpha\left(\dot{v}+\dot{P}_{p}\right)-\dot{L}-\dot{P}_{c} \\
& =\alpha \dot{v}-\dot{L}+\alpha \dot{P}_{p}-\dot{P}_{c} \\
& \text { (Output Effect - Employment Effect + Price Effect) }
\end{aligned}
$$

The trend rate of growth of real wages is thus seen in equation (2a) to be the sum of three effects: the output effect is the first term of the right hand side, the employment effect is the second term and the sum of the third and fourth is the price effect. The equation focuses our attention on employment elasticity as 
being an outcome of the trade-off between employment growth and wage growth. But it is seen that the borders of this trade off are governed by three variables: output growth; the value of the $\alpha$ parameter determining the trend in the share of wages; and the price effect. The equation shows that real wage growth is higher the lower is employment growth. But two other factors have an impact upon it: the output effect, which is the part of the real wage increase ascribed to real growth in value added, given the value of $\alpha$; and the last two terms, showing the impact of changes in the price levels facing producers and consumers over time.

The price effect is really composed of two distinct elements. The last two terms in equation (2a) could be re-written as:

$$
(\alpha-1) \dot{P}_{p}+\left(\dot{P}_{p}-\dot{P}_{c}\right)
$$

The first term in (3) could be called the wage share effect of price changes over time. If $\alpha<1$ the share of wages in net output falls over time in current prices in accordance with equation (1). In this case the first term in (3) is negative, showing that a certain part of the real output growth, as measured by this term, is not available for the growth of the real wage bill. It is clear that the higher the inflation rate the greater will be the leakage from the available wage bill in real terms to support wage and/or employment growth. As mentioned above (Section 2.1) this effect can be traced to the lag in the adjustment of wage to the inflationary increase in prices. The second term is the rate of change in the ratio of producer to consumer prices or the so-called domestic real exchange rate (DRER). One can intuitively grasp its importance by considering the case of an inflationary economy in which the exchange rate depreciation lags behind the rate of inflation--a common enough scenario in developing countries. In this case the consumer price level that affects the real value of workers' wages, increases faster than producer prices that are tied to international prices of traded goods. Thus the second term in (3) is also negative implying that a portion of the real output growth is used to keep the wage bill growing at the same real rate. Both these price effects, if negative, can be thought of as leakages from the real output growth, which decrease the rate of growth of the portion available for supporting either employment or real wage growth. 


\section{APPENDIX 2}

It might be worthwhile to set out the equations of the system discussed verbally in

Section II. We look at the picture at a slice of time when the system is in steady equilibrium along its growth path. The definitions of the variables are as follows:

$$
\begin{aligned}
& \mathrm{P}=\text { profits of the firm in the period in question } \\
& \mathrm{I}=\text { investment Planned for the period } \\
& \mathrm{V}=\text { Value Added produced by the investment } \\
& \mathrm{L}=\text { number of workers employed } \\
& \mathrm{l}_{\mathrm{e}}=\text { number of efficiency units supplied per worker } \\
& \mathrm{L}_{\mathrm{e}}=\text { total labor employed in efficiency units } \\
& \mathrm{W}=\text { wage bill } \\
& \mathrm{W}=\text { wage per worker employed } \\
& \mathrm{W}_{\mathrm{e}}=\text { wage cost per efficiency unit of work supplied }
\end{aligned}
$$

The system pf equations can then be written as follows:

$$
\begin{aligned}
& \text { Production Function: } \\
& \mathrm{V}=\mathrm{f}\left(\mathrm{I} / \mathrm{L}_{\mathrm{e}}\right) \\
& \text { Financing of Investment: } \\
& \mathrm{I} / \mathrm{V}=\mathrm{g}(\mathrm{P} / \mathrm{V}) \ldots \quad \text { (2) } \\
& \text { Choice of Technique: } \\
& \mathrm{I} / \mathrm{L}_{\mathrm{e}}=\mathrm{h}\left(\mathrm{w}_{\mathrm{e}}\right) \ldots \\
& \text { Efficiency Wage Function: } \\
& 1_{\mathrm{e}}=\mathrm{i}(\mathrm{w}) \ldots \ldots \\
& \mathrm{V}=\mathrm{P}+\mathrm{W} \ldots \ldots \\
& \mathrm{L}_{\mathrm{e}}=\mathrm{L} . \mathrm{l}_{\mathrm{e}} \ldots \ldots \\
& \mathrm{W}=\mathrm{L} . \mathrm{W} \quad \ldots \quad \ldots \\
& \mathrm{W}=\mathrm{L}_{\mathrm{e}} \cdot \mathrm{W}_{\mathrm{e} \ldots} . . \\
& \mathrm{w}_{\mathrm{e}}=\mathrm{w} / \mathrm{l}_{\mathrm{e}} \ldots \quad \ldots
\end{aligned}
$$

There are nine unknowns $\mathrm{V}, \mathrm{I}, \mathrm{L}, \mathrm{L}_{\mathrm{e}}, \mathrm{P}, \mathrm{W}, \mathrm{w} . \mathrm{w}_{\mathrm{e}}$ and nine equations to determine them. In Appendix 3 we take a slice of this system and examine a bit more carefully how the share of profits adjusts to the investment rate which is desired.

\section{APPENDIX 3}

\section{A Model of Investment Rate and the Share of Wages(Profits)}

The following additional definitions apply:

$\sigma=$ productivity of the capital investment

$\mathrm{Sp}=$ propensity to save of entrepreneurs out of profits

In the equilibrium portrayed in Figure II. 1 it is assumed that the wage per man has been determined within the constraints of institutional factors mentioned in the text. Thus the both the supply of work units per worker and the wage cost per work unit is determined, and it is 
assumed it is constant for the range of work units needed. For any share of profits in value added P/V (and hence the wage bill) we then have a supply of work units forthcoming as the product of number of workers and the supply of work units per worker. The curve in the fourth quadrant is the result of the production function - combining the capital used (as determined by the investment ratio corresponding to the profit share) with the quantity of work units available. It shows diminishing return to the use of capital per work unit (for a given technology and economic environment of the period in question). As $\mathrm{K} / \mathrm{L}$ increase with $\mathrm{I} / \mathrm{V}$ along the $\mathrm{y}$-axis of this quadrant, the productivity of capital $\sigma$ falls.

The curve in quadrant I on the other hand shows the feasibility of sustaining different values of profit share. The profit share is the residual from the value added after the predetermined wage bill is deducted. Obviously it increases with the productivity of capital $\sigma$ (some non-linearity in the function is allowed in the diagram to allow for increase in marketing costs but this detail is unimportant).

- In equilibrium the share of profits which is attained in any period must satisfy both the $\sigma$ and the share of investment (I/V) which is desired. But given the production function, $\sigma$ varies with the amount of investment and hence with $\mathrm{I} / \mathrm{V}$. If the system is to stay in equilibrium the $\sigma$ yielded by the production function has to be consistent with that yielded by the feasibility function of Quadrant I.. The full equilibrium can be described in the diagram shown as figure II.1.

Quadrant 2 depicts the relationship between the Investment ratio (I/V) on the $\mathrm{x}$-axis and the profit share on the vertical. Following Kaldor (but not invoking the aggregate demand or macro-economic aspects of his analysis) the relationship is a straight line at an angle less than 45 degree to the vertical axis, i.e., a slope of $S_{p}$ (less than one ) where $I / V=S_{p}(P / V), S_{p}$ being the propensity to save of the profit earners. The straight line in quadrant 3 copies the investment ratio from quadrant 3 to the vertical axis of quadrant 4 .

The dotted lines show the full equilibrium of the system in any period. The planned $\mathrm{I} / \mathrm{V}$ ratio at the beginning of the period must be sustained by a level of $\sigma$ and a share of profits as shown in quadrants 4 and 2 respectively, and both must be consistent with each other as per the relationship shown in quadrant 1 . Any attempt, given the production function and market conditions, to increase I/V leads to a lower $\sigma$ and a hence lower $\mathrm{P} / \mathrm{V}$ than what is required to finance the investment. The wage-price nexus required to support the increased I/V fails as it comes up against the inflation barrier posed by the labor market and/or the loss of competitiveness in the product market. 
The reform process, as with the liberalization in India, by relaxing the constraints on the markets for inputs and outputs, can be expected to shift the production function upwards, and thus the schedule in quadrant 4 relating I/V to capital productivity shifts outwards. Firms can then sustain a higher I/V ratio relative to the pre-reform situation with a higher $\sigma$ and a higher profit ratio.

Firms differ in their levels of capital productivity. Thus comparing equilibrium positions across firms or groups of firms (or industries), we get a testable hypothesis:

Hypothesis 1. The share of profits (wages) will be higher (lower) the higher (lower) the I/ ratio and the level of capital productivity.

\section{Disequilibrium situations}

In any period, it would be unusual for the system to be in complete equilibrium. But any deviation from it would tend to be corrected in the next period. Thus suppose entrepreneurs plan a certain $\mathrm{I} / \mathrm{V}$ ratio on the basis of information about the profit share and capital productivity in period $\mathrm{t}-1$. They would expect the system to be in equilibrium with these values of the three variables in period t. But suppose capital productivity falls short of the expected value in period t. Then $\mathrm{P} / \mathrm{V}$ is not large enough to sustain the planned $\mathrm{I} / \mathrm{V}$, and in planning for the next period entrepreneurs would aim at a lower I/V unless they have reason to believe that the shortfall was due to exceptional events. Considering that the observed points of different combinations of the three variables are likely to be a series of disequilibrium points, we have a hypothesis much like Hypothesis 1 above. In other words:

Hypothesis 2. Even if we do not have firms differing in their levels of capital

productivity in equilibrium, we would expect to see that the observed share of profits (wages) is directly (inversely) related to the investment ratio and capital productivity. 
Figure II.1: The Equilibrium with Capital Productivity $(\sigma)$ Profit Share (P/V) and Investment Share (I/V)

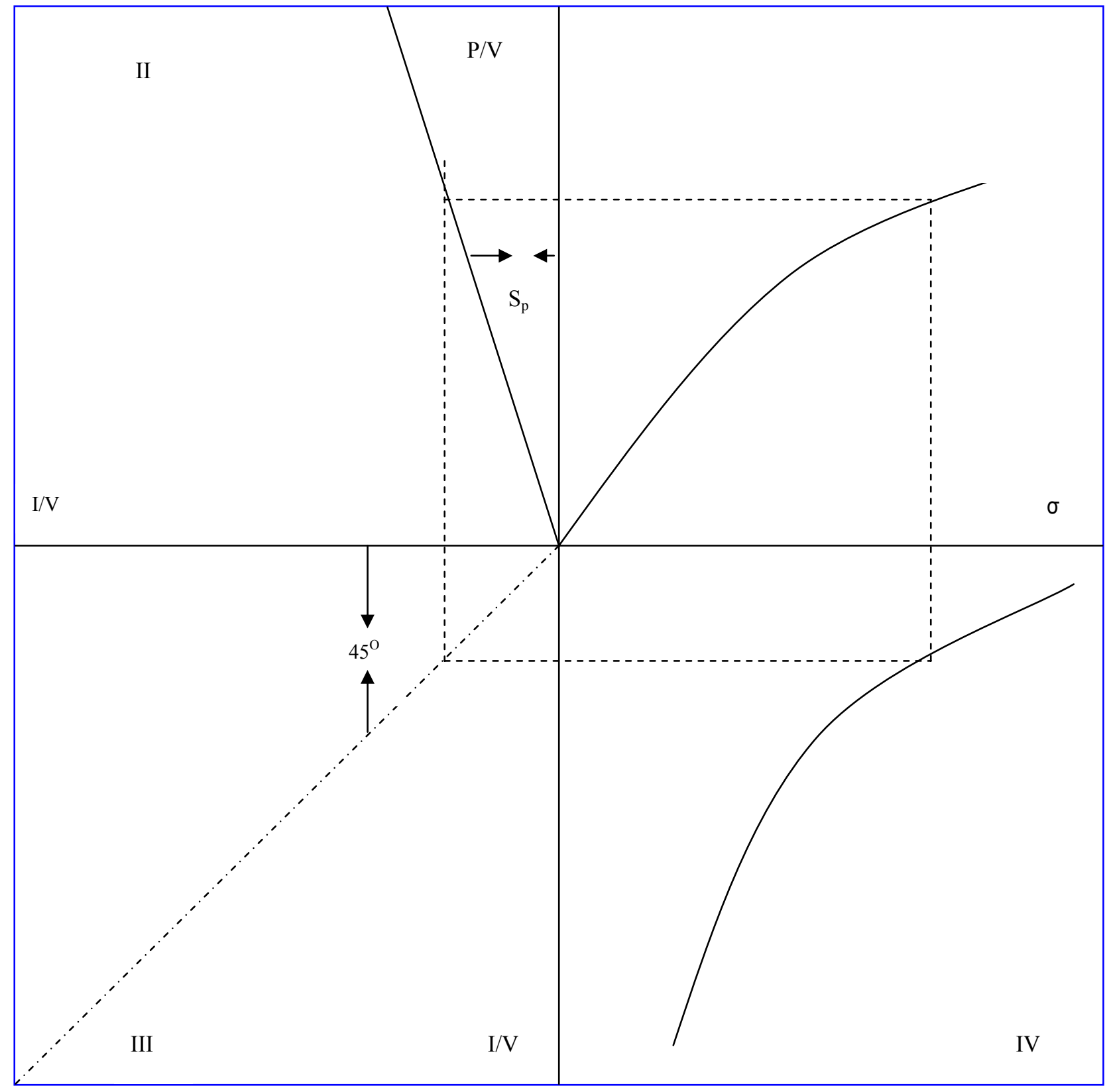




\section{Testing the hypotheses}

We tested the hypotheses emerging in the discussion of the last section by regressing the value of $\alpha$, the elasticity of the wage bill with respect to value added (and hence determining the trend in the share of wages) on the investment ratio and capital productivity in Indian manufacturing. ${ }^{4}$ The data for the years from 1986-87 to $1994-95$ by the five sizeclasses of firms were pooled together. Since we get only nine observations for each size class, it was decided to test a fixed effect model (i.e. a pooled regression model with sizegroup dummies). The results are presented in table II.1.

Table II.1 Regression results for Alpha ( $\alpha$ )

\begin{tabular}{|l|r|r|r|}
\hline Dependent Variable: & $\alpha$ & \multicolumn{3}{|c|}{$\alpha$} \\
\hline Model: & Fixed Effect Model with size dummies \\
\hline \multicolumn{4}{|c|}{ F- } \\
$\mathrm{R}^{2}=$ & 0.715 & \multicolumn{1}{l|}{ values $=$} \\
\hline Variables & Estd. Coeff. & t-values & \multicolumn{1}{|c|}{ Sig. } \\
\hline Constant & 1.55415 & 9.03 & 0.000 \\
\hline Investment ratio & -0.00190 & -3.76 & 0.001 \\
\hline Capital productivity & -0.00001 & -3.65 & 0.001 \\
\hline Size Dummies & \multicolumn{4}{|c|}{} \\
\hline 1.50-199 & -0.246 & -5.43 & 0.000 \\
\hline 2. 200-499 & -0.295 & -5.40 & 0.000 \\
\hline 3. 500-999 & -0.434 & -6.71 & 0.000 \\
\hline 4. $1000 \&$ above & -0.449 & -5.84 & 0.000 \\
\hline
\end{tabular}

Note: The constant term absorbs the effect of the excluded dummy variable size-group 10-49. The estimated values of the other size dummies are with respect to the excluded size-group.

The result shows that both investment ratio and capital productivity are negatively related to dependent variable $\alpha$. The coefficients of size dummies are also negative relative to the smallest size class of 10-49 workers, showing that the effect of size on alpha is negative. All the independent variables are significant.

The results are consistent with the predictions of our model, remembering that the hypotheses - in both the equilibrium and disequilibrium situations, were couched in terms of the share of profits - which behaves inversely to the change in the share of wages. The negative relationship of the share of wages to the size dummies - i.e. the positive relationship of the profit

\footnotetext{
${ }^{4}$ Note that the coverage of the Annual Survey of Industries - which we use - is confined to large factories employing 10 or more workers in units using power and $20+$ workers in units not using power.
} 
share - can be interpreted as the impact of technology differences. Large firms plausibly have a higher level of higher level of capital productivity.

In the regression model of table IV.5 the absolute value of capital productivity has been used. We have also tried an alternative specification of capital productivity, viz. taking capital productivity of each size class for the year 1986-87 as 100 and then calculating the capital productivity separately for each class for successive years. Such a specification neutralises the initial disparity in capital productivity as between different size classes. The estimated coefficient of capital productivity in this specification also turned out to be significantly negative.

The results lend support to the conclusions from the Kalecki model outlined above. The increased rate of investment induces the dynamic firm to plough back the surplus above material and wage costs into the financing for investment. The decrease in the share of wages, which this process involves, is possible because of the increase in total factor productivity. The higher rate of surplus can be generated without a decrease in the rate of growth of real wages and of employment below a threshold, which might have triggered worker resistance, or a potential shortage of labour of requisite skills. As we have seen, the fall in the share of wages in value added in the third period was accompanied by a much reduced rate of real wage growth, but it continued to be positive, and the rate of employment growth actually increased substantially. 


\section{REFERENCES}

Asimakopoulos, M. (1971), 'The Determinants of Investment in Keynes's Model', Canadian Journal of Economics, Vol. 4, No. 3, pp.382-388.

Bhalotra, Sonia R.. 1998. 'The Puzzle of Jobless Growth in Indian Manufacturing', Oxford Bulletin of Economics and Statistics vol. 60 (1), pp.5-32.

Eichner, Alfred S. (1973) 'A Theory of the Determination of the Mark-up' Economic Journal, 83, no. 332, 1184-1200.

Fallon, P and R E B Lucas. (1993), "Job Security Regulations and the Dynamic Demand of Industrial Labour in India and Zimbabwe', Journal of Development Economics, vol 40, pp. 241-75.

Ghose, Ajit K.(1994), 'Employment in Organized Manufacturing in India', Indian Journal of Labor Economics, Vol, 37, no. 2, April-June, pp.141-62.

Ghose, Ajit K. (2003). 'Jobs and Income in a Globalizing World, ILO, Geneva.

Government of India (2002). Report of the Special Group on Targeting Ten Million Employment Opportunities per Year over th3 $10^{\text {th }}$ Plan Period. Reproduced in Planning Commission Reports on Labor and Employment, Academic Foundation, New Delhi

Kalecki, M. (1941) 'A Theory of the Long-run Distribution of the Product of Industry' Oxford Economic Papers (Old Series), 5, June, 31-41

Kalecki, M. (1954) Theory of Economic Dynamics. Allen and Unwin, London.

Kalecki,M. (1938) 'The Determinants of Distribution of the National Income' Econometrica, 6,2, 97-112.

Kalecki, M. (1971). 'Selected Essays on Dynamics of the Capitalist Economy, 1933-1970', Cambridge University Press, London.

Mazumdar, Dipak. (2003). 'Trends in Employment and the Employment Elasticity in Manufacturing, 197192: An International Comparison', Cambridge Journal of Economics, 27,4, 563-582

Morawetz, D. (1974). 'Employment Implications of Industrialization in Developing Countries', Economic Journal, vol. 84, no. 335, pp 491-542.

Nagraj, R. (1994), 'Employment and Wages in Manufacturing Industries: Trends, Hypotheses and Evidence', Economic and Political Weekly, vol. 29, no. 4, January 22, pp. 177-86.

Papola, T.S. (1992). 'Labour Institutions and Economic Development: The Case of Indian Industrialization' in Papola, T.S. and Rodgers, G. (eds), Labour Institutions and Economic Development in India, IILS Research Series no. 97, ILO, Geneva.

Roy, Tirthankar (2002). 'Social Costs of Reforms: A study of job loss with special reference to declining industries in 1990-98" Chapter in Uchikawa (2002) pp. 99-126.

Uchikawa, Shuji, Ed. (2002). Economic Reforms and Industrial Structure in India. Manohar, New Delhi 
Uchikawa, Shuji, Ed. (2003) Labour Market and Institutions in India: 1990s and Beyond. Institute of Developing Economies, Tokyo.

Uchikawa, U.(2001), 'Investment Boom and Underutilisation of Capacity in the 1990s', Economic and Political Weekly, August 25.

World Bank, (1989), India: Poverty, Employment and Social Services: A World Bank Country Study, World Bank, Washington D.C. 